\title{
Chemometrically assisted optimization, development and validation of UPLC method for the analysis of simvastatin
}

\author{
Maja Hadzieva Gigovska ${ }^{1 *}$, Ana Petkovska ${ }^{1}$, Blagica Manchevska ${ }^{1}$, Jelena Acevska ${ }^{2}$, \\ Natalija Nakov ${ }^{2}$, Packa Antovska ${ }^{1}$, Sonja Ugarkovic ${ }^{1}$, Aneta Dimitrovska ${ }^{2}$ \\ ${ }^{1}$ Research \& Development, ALKALOID AD Skopje, Blvd. Aleksandar Makedonski 12, \\ 1000 Skopje, R. Macedonia \\ ${ }^{2}$ Faculty of Pharmacy, Ss. Cyril and Methodius University, Mother Theresa 47, \\ 1000 Skopje, R. Macedonia
}

Received: September 2018; Accepted: November 2018

\begin{abstract}
This manuscript presents chemometrically assisted optimization and validation of UPLC method intended for the quantitative analysis of simvastatin in pharmaceutical preparations. To achieve the desired chromatographic response and to simultaneously optimize the most important chromatographic parameters with a limited number of experiments in a minimum amount of time, Box-Behnken design was used.

The separation was performed on Poroshell 120 EC C18 50 × $3.0 \mathrm{~mm} 2.7 \mu \mathrm{m}$, using $10 \mathrm{mM}$ ammonium formate pH 4.0 and acetonitrile as the mobile phase. To obtain complete information about method performance and robustness, seven factors (column type, acetonitrile content, temperature, $\mathrm{pH}$ of mobile phase, molarities of ammonium formate, flow rate and wavelength) were assessed in twelve experiments according to Plackett-Burman design. The proposed method was validated according to International Conference on Harmonization ( $\mathrm{ICH}$ ) guidelines to confirm specificity, linearity, precision, detection and quantification limits. Validation results have shown that the proposed method is selective, linear, accurate, sensitive (LOD $0.06 \mu \mathrm{g} / \mathrm{mL}$ and LOQ $0.18 \mu \mathrm{g} / \mathrm{mL}$ ), and robust and it is suitable for quantitative determination of simvastatin in pharmaceutical preparations.

The optimized and validated method gives rapid and efficient separation and represents an improvement over the existing methods especially in the terms of sensitivity, low cost of analysis per sample and the environmental impact of the method.
\end{abstract}

Keywords: chemometry, design of experiments, UPLC/DAD, simvastatin

\section{Introduction}

Simvastatin (SIM) is a lipid regulating agent belonging to a group of pharmaceuticals called statins that has been confirmed to be efficacious in the treatment of hypercholesterolemia and dyslipidemia (Tripathi, 2008). SIM is an inactive prodrug that competitively inhibits hydroxyl methyl glutaryl coenzyme A (HMG-CoA) reductase. Besides regulating synthesis of cholesterol, statins also inhibit the production of mevalonate and downstream isoprenoids which contribute to the effects of statins on diseases such as prostate cancer, auto-immune diseases, and neurological disorders among others (Bifulco and Endo, 2014; Sirtori, 2014; Mozaffarian et al., 2004). So lately, statins are becoming well-known for their cholesterol-independent effects and their potential use in brain diseases and different types of cancers. This has opened a great interest within the scientific community for analytical methods for their quantification.

$\overline{* \text { hadzievam@yahoo.com }}$ 
Modern pharmaceutical analysis requires more sophisticated approach for development and optimization of chromatographic analysis, which will allow better understanding of all factors affecting the separation and science-based methodology that can fulfill the requirements of new analytical challenges.

Recently, chemometric approach is considered as precious complement to chromatographic analysis, since many variables can be simultaneously controlled to achieve the desired separations. Moreover, chemometrics efficiently identify and optimize the significant factors to accomplish reliable results through limited experimental trials (Duarte and Capelo, 2006).

Literature survey reveal several review papers dealing with the description of experimental design usage in chromatography, where increasing trend of application of chemometrics in chromatography is noticed (Cela et al., 2013; Dejaegher and Vander Heyden, 2011; EbrahimiNajafabadi et al., 2014a; Ebrahimi-Najafabadi et al., 2014b; Ferreira et al., 2007; Ganorkar and Shirkhedkar, 2017; Hibbert, 2012).

Although some methods have been developed for the determination of SIM, including the two official methods reported in European Pharmacopeia and United State pharmacopoeia utilizing HPLC gradient elution, to the best of our knowledge, there are no references in the literature concerning chemometrics approach used for development and validation of UPLC method intended for quantitative analysis of SIM in pharmaceutical preparations (Abu-Nameh et al., 2006; Álvarez-Lueje et al., 2005; Guzik et al., 2010; Jat et al., 2012; Reddy et al., 2014). The reported analytical method mostly focused on systematic optimization procedure, but employed a timeconsuming trial-and error approach resulting only in an apparent optimum and provides limited understanding of a method's capabilities and robustness and interaction between factors are not provided.

Therefore, the aim of present study was to develop, optimize and validate sensitive, robust and cost-effective UPLC method using chemometric approach. BoxBehnken design was employed at the optimization step, while in the robustness evaluation Plackett-Burman design enabled anticipation of the system behavior under real operational conditions.

Due to scientific and public concern about the environment pollution, environmentally friendly practices have been introduced in different areas of society and research including UPLC method development (Gaber et al., 2011). As a consequence of the aforementioned problems together with the current "green" movement to protect and promote the sustainable environment, there is need of method for determination of SIM to ensure regulatory complaints as per Harmonized tripartite ICH Guidelines which meets the green aspects in analytical chemistry.

\section{Material and methods}

\section{Chemicals and standards}

Simvastatin CRS (purity 99.7\% "as is"), Simvastatin for peak identification, Simvastatin Impurity $E$ (Lovastatin) were provided by European Directorate for the Quality of Medicines and Health Care Council of Europe (EDQM-Strasbourg, France).

SIM, active substance samples with certificate of suitability to the monographs of the European Pharmacopeia (CEP), received as free sample from Teva Pharmaceutical Industries Ltd. Israel, were used.

The analyzed pharmaceutical dosage form was filmcoated tablets containing $10 \mathrm{mg}$ of SIM (Alkaloid AD Skopje, Macedonia).

Analytical grade acetonitrile $\left(\mathrm{CH}_{3} \mathrm{CN}\right)$, ammonium formate $\left(\mathrm{NH}_{4} \mathrm{COOH}\right)$, formic acid $(\mathrm{HCOOH})$, sodium hydroxide $(\mathrm{NaOH})$, hydrochloric acid $(\mathrm{HCl})$ and hydrogen peroxide $\left(\mathrm{H}_{2} \mathrm{O}_{2}\right)$ were purchased from Merck (Darmstadt, Germany). Water was purified by a Werner water purification system, obtained in-house at Alkaloid AD Skopje, Skopje, Macedonia. Regenerated cellulose membrane syringe filters with pore size $0.45 \mu \mathrm{m}$, were purchased from Phenomenex (Torrance, CA. USA).

\section{Chromatographic conditions}

Experiments were performed on Agilent Technologies 1290 Infinity Liquid Chromatographic System (Agilent Technologies, USA) equipped with a Quaternary Pump VL, a column compartment, auto sampler and photo-diode array detector. Instrument control, data acquisition and processing were done by using OpenLab Chemstation chromatography software (version A.02.02/1.3.4). The separation was performed on Poroshell 120 EC C18 (Agilent Technologies, USA), $50 \mathrm{x}$ $3.0 \mathrm{~mm}, 2.7 \mu \mathrm{m}$ using buffer (10 $\left.\mathrm{mM} \mathrm{NH}_{4} \mathrm{COOH}, \mathrm{pH} 4.0\right)$ and $\mathrm{CH}_{3} \mathrm{CN}$ as a mobile phase in ratio 40: $60(\mathrm{v} / \mathrm{v})$. The column temperature was $40{ }^{\circ} \mathrm{C}$. Flow rate was 0.5 $\mathrm{mL} / \mathrm{min}$. Injection volume was $5 \mu \mathrm{L}$. UV detection was performed at $238 \mathrm{~nm}$.

The experimental design for the optimization and robustness testing, along with statistical analysis of data was performed with Design-Expert software, Version 7.0.0 (Stat Ease Stat-Ease, Inc., Minneapolis, MN, USA).

\section{Standard and sample preparation}

Standard solution of SIM in final concentration of 30 $\mu \mathrm{g} / \mathrm{mL}$ was used for quantitative determination. Mixture of SIM in concentration of $30 \mu \mathrm{g} / \mathrm{mL}$ and Simvastatin Impurity $\mathrm{E}$ (Lovastatin) in concentration of $0.3 \mu \mathrm{g} / \mathrm{mL}$ was used as a resolution solution. Amount of $5 \mathrm{mg}$ "simvastatin for peak identification" corresponding to a mixture of SIM and its related impurities (A, B, C, D, E 
and F), which are specified and described in the European Pharmacopoeia monograph, was dissolved in $5.0 \mathrm{~mL}$ diluent and used as system suitability solution. Mixture of $\mathrm{CH}_{3} \mathrm{CN}$ and water in the ratio of 50: $50(\mathrm{v} / \mathrm{v})$ was used as a diluent.

The concentration of SIM in samples described in this study was $30 \mu \mathrm{g} / \mathrm{mL}$. To verify the specificity and the stability indicating power of the proposed method SIM was subjected to stress under acidic, alkaline, oxidative, thermal and photolytic conditions.

Acid degradation was made using $2 \mathrm{~mL}$ SIM stock solutions $(10.0 \mathrm{mg} / \mathrm{mL})$ treated with $2.0 \mathrm{~mL} 0.1 \mathrm{M} \mathrm{HCl}$ at $25^{\circ} \mathrm{C}$ for 15 minutes. At the end of exposure, the samples were neutralized with $2.0 \mathrm{~mL} 0.1 \mathrm{M} \mathrm{NaOH}$ and diluted to final concentration of $30 \mu \mathrm{g} / \mathrm{mL}$ with diluent.

For alkali degradation $2 \mathrm{~mL}$ SIM stock solution (10.0 $\mathrm{mg} / \mathrm{mL}$ ) were treated with $2.0 \mathrm{~mL} 0.1 \mathrm{M}$ sodium $\mathrm{NaOH}$ at $25^{\circ} \mathrm{C}$ for 15 minutes. At the end of exposure, the samples were neutralized with $2.0 \mathrm{~mL} 0.1 \mathrm{M} \mathrm{HCl}$ and diluted to final concentration of $0.03 \mathrm{mg} / \mathrm{mL}$ with diluent.

Oxidative study was carried out at room temperature with $3 \% \mathrm{H}_{2} \mathrm{O}_{2}$ for 60 minutes. For thermal degradation SIM was exposed at $105^{\circ} \mathrm{C}$ for 5 hours.

Photo degradation study was performed by exposing the drug powder, spread as a thin film in a quartz Petri plates and exposed to direct sunlight for 24 hours. Additionally, control study in dark was run simultaneously.

Applicability of this method in pharmaceutical preparations was evaluated by analyzing the samples of commercially available formulations (film coated tablets) that contain $10 \mathrm{mg}$ SIM. Sample equivalent to $30 \mathrm{mg}$ of SIM was taken in a $100 \mathrm{~mL}$ volumetric flask. Appropriate dilutions were carried out to obtained solution with concentration of $30 \mu \mathrm{g} / \mathrm{mL}$ and analyzed according to the optimized chromatographic conditions.

\section{Method optimization}

The optimization of the chromatographic method involved investigation of the quantitative effects of different experimental variables on the performance of chromatographic separation using a chemometric approach. The Box-Behnken design approach was used in order to study the individual and combined effects of three independent factors, i.e. the percent of organic modifier in the mobile phase $\left(x_{1}\right)$, column temperature $\left(x_{2}\right)$ and flow rate $\left(x_{3}\right)$ on the chosen responses -SIM peak retention time (Rt), tailing $(\mathrm{T})$, resolution of the chromatographic separation (Rs) and number of theoretical plates (NTP). The range and the levels of experimental investigated variables are presented in Table 1.

According to the International Conference on Harmonization (ICH) the evaluation of the method robustness should be evaluated in the development and optimization phase of the method (Ich 2005).

In this case, the method robustness was studied by testing the influence of small changes of column temperature $\left( \pm 5^{\circ} \mathrm{C}\right)$, organic content of mobile phase $( \pm$ $3 \%)$, flow rate $( \pm 0.1$ units), wavelength $( \pm 2 \mathrm{~nm})$ and the use of different lot of the chromatographic column (Table 2).

Additionally, seven factors (column, acetonitrile content, temperature, $\mathrm{pH}$ of mobile phase, molarity of ammonium formate, flow rate and wavelength) were assessed in twelve experiments according to PlackettBurman design, to obtain complete information about the method performance.

The Plackett-Burman design was completed by the addition of 4 dummy factors. Dummy variables are imaginary factors whose changes do not affect the system and are added to provide statistical evaluation of the results. For each of the 12 experiments, 3 injections (diluent, resolution solution and standard solution) were performed. Plan of the experiments defined by the Plackett-Burman design and the obtained results are given in Table 2 .

\section{Solutions for validation}

Following the chromatographic conditions, the method was validated according to $\mathrm{ICH}$ guidelines, to evaluate the method for selectivity, linearity of response, accuracy, precision, recovery, limit of detection and quantification, robustness and stability of solutions.

To study the linearity of the response, a series of three injections of standards at ten different concentrations that span from 1 to $150 \%$ of the standard's working range were analyzed.

The accuracy of the method was determined in triplicate at three concentration levels of 50, 100 and $150 \%$ by spiking the prequantified samples with a known amount of SIM standard.

Table 1. Factors and levels of the Box-Behnken experimental plan

\begin{tabular}{lcccc}
\hline \hline \multirow{2}{*}{ Factor } & \multirow{2}{*}{ Code Range } & \multicolumn{3}{c}{ Levels $^{\text {a }}$} \\
\cline { 3 - 5 } & & -1 & 0 & +1 \\
\hline \% Organic modifier (acetonitrile) & $x_{1}$ & 50 & 60 & 70 \\
Column temperature $\left({ }^{\circ} \mathrm{C}\right)$ & $x_{2}$ & 25 & 30 & 40 \\
Flow (mL/min) & $x_{3}$ & 0.4 & 0.5 & 0.6 \\
\hline
\end{tabular}

${ }^{\mathrm{a}}$ Aberrations: -1 = low factor level, $+1=$ high factor level 
Table 2. The selected Plackett-Burman design for verification of the robustness of proposed method

\begin{tabular}{|c|c|c|c|c|c|c|c|c|c|c|c|c|c|c|c|}
\hline \multirow{2}{*}{$\begin{array}{l}\text { Number } \\
\text { experiments }\end{array}$} & \multicolumn{11}{|c|}{ Factors levels $^{\mathrm{b}}$} & \multicolumn{4}{|c|}{ Responses } \\
\hline & $x_{I}$ & $x_{2}$ & $x_{3}$ & $x_{4}$ & $x_{5}$ & $x_{6}$ & $x_{7}$ & $x_{8}$ & $x_{9}$ & $x_{10}$ & $x_{11}$ & $\mathrm{Rt}$ & $\mathrm{T}$ & Rs & NTP \\
\hline 1 & 8 & 240 & 35 & -1 & 4.2 & 0.4 & 65 & -1 & -1 & 1 & 1 & 3.156 & 1.04 & 5.40 & 6236 \\
\hline 2 & 12 & 236 & 45 & -1 & 3.8 & 0.6 & 65 & -1 & -1 & -1 & -1 & 1.960 & 1.02 & 5.10 & 6628 \\
\hline 3 & 12 & 240 & 35 & -1 & 4.2 & 0.6 & 55 & 1 & 1 & -1 & 1 & 1.952 & 1.03 & 5.22 & 6180 \\
\hline 4 & 12 & 240 & 45 & 1 & 3.8 & 0.4 & 65 & -1 & 1 & -1 & 1 & 4.370 & 1.02 & 7.26 & 6814 \\
\hline 5 & 8 & 236 & 35 & -1 & 3.8 & 0.4 & 55 & 1 & -1 & -1 & -1 & 6.495 & 0.95 & 6.97 & 6011 \\
\hline 6 & 8 & 236 & 45 & 1 & 4.2 & 0.6 & 55 & 1 & 1 & -1 & -1 & 4.055 & 1.02 & 7.05 & 6713 \\
\hline 7 & 12 & 236 & 35 & 1 & 4.2 & 0.4 & 65 & -1 & -1 & -1 & 1 & 3.196 & 1.03 & 5.50 & 6307 \\
\hline 8 & 12 & 236 & 45 & 1 & 4.2 & 0.4 & 55 & 1 & -1 & 1 & -1 & 6.088 & 1.01 & 6.83 & 6300 \\
\hline 9 & 8 & 240 & 45 & -1 & 4.2 & 0.6 & 65 & 1 & 1 & 1 & -1 & 1.970 & 1.04 & 5.10 & 6184 \\
\hline 10 & 8 & 236 & 34 & -1 & 3.8 & 0.6 & 65 & 1 & 1 & 1 & 1 & 2.130 & 1.04 & 5.42 & 6389 \\
\hline 11 & 8 & 240 & 45 & 1 & 3.8 & 0.4 & 55 & -1 & 1 & 1 & -1 & 6.040 & 0.95 & 6.60 & 5907 \\
\hline 12 & 12 & 240 & 35 & 1 & 3.8 & 0.6 & 55 & -1 & -1 & 1 & 1 & 4.333 & 1.01 & 7.22 & 6777 \\
\hline
\end{tabular}

\footnotetext{
b Aberrations: $x_{1}$ - content of ammonium formate $(\mathrm{mM}) ; x_{2}$ - wavelength; $x_{3}$ - column temperature; $x_{4}$ - column of the same composition but of different lot Column 1: Poroshell 120 EC C18 50 x 3.0 mm, 2.7 $\mu \mathrm{m}$ (lot. USCFZ13194/B13243),

Column -1: Poroshell 120 EC C18 50 x 3.0 mm, 2.7 $\mu \mathrm{m}$ (lot. USCFZ13193/B13243);

$x_{5}-\mathrm{pH}$ of the mobile phase; $x_{6}$ - flow rate; $x_{7}$ - content of acetonitrile $(\%) ; x_{8^{-}} x_{12}$ - dummy factors;

-1 = low, 1 = high factor level
}

In the precision study, repeatability and intermediate precision tests were carried out. The repeatability was shown by 6 replicate injections of the standard solution in concentration of $30 \mu \mathrm{g} / \mathrm{mL}$ and the intermediate precision was performed on 10 samples in two following days using the same equipment.

The sensitivity of the analytical method was evaluated by determining the detection limit (LOD) and quantitation limit (LOQ) using the signal-to noise ratio method, i.e. the concentrations yielding to signal-to-noise ratios of 3:1 and 10:1 were considered as LOD and LOQ, respectively.

The suitable filter was selected by performance of the absorbance filter test. The standard solution was filtered through four different filters: regenerate cellulose (RC), polytetrafluoroethylene (PTFE), hydrophilic polypropylene (GHP) and Nylon (NY) membrane filter with a $0.2 \mu \mathrm{m}$ pore size. The areas obtained from six individually filtered aliquots of standard solution in concentration of $0.03 \mathrm{mg} / \mathrm{mL}$ were compared with the area of appropriate unfiltered standard solution.

The stability of the standard solution and the sample solution was evaluated by analyzing the same sample immediately after preparation and after time interval $(0,12$ and $24 \mathrm{~h}$ ) by keeping the solution at room temperature.

\section{Results and discussion}

\section{Optimization design and analysis}

The experimental design technique used for this study was Box-Behnken design. This design helps to investigate the effects of three factors (independent variables), each varied at three levels. Decision concerning selection of the factors, levels and responses were made based on preliminary experiments and prior knowledge from literature.

The reported methods for determination of SIM describe RP-HPLC procedures employing various $\mathrm{C} 18$ columns (Abu-Nameh et al., 2006; Álvarez-Lueje et al., 2005; De1 et al., 2013; Guzik et al., 2010; Jat et al., 2012; Reddy et al., 2014). Considering the lipophilic nature of the analyte, the C18 packing columns were shown to be the most suitable. Initially, four columns were examined (Zorbax Extend C18, Zorbax Eclipse C18, Zorbax XDB C18 and Poroshell 120 EC C18) and it was decided to continue the investigation on Poroshell 120 EC C18 $50 \mathrm{x}$ $3.0 \mathrm{~mm}, 2.7 \mu \mathrm{m}$. This decision was based on the properties of this column, which is packed with specific, spherical core shell particles, allowing high efficiency of separation. The use of this column enabled tight, symmetrical peak with good resolution.

It was decided to use acetonitrile as an organic modifier, since better peak symmetry and shorter analysis run time were obtained. The addition of buffer was inevitable, thus three buffers suitable for LC/MS analysis were examined (ammonium formate, ammonium acetate and trifluoroacetic acid). Concentrations of these buffers were varied in the range from $5-10 \mathrm{mM}$. Minimum analysis time and good chromatographic peak shape was obtained using $10 \mathrm{mM}$ ammonium formate buffer.

In this work, the important chromatographic factors were selected and optimized by a Box-Behnken experiment. In accordance with the Box-Behnken design, 
Table 3. Box-Behnken experimental design matrix of the selected independent variables and studied responses

\begin{tabular}{|c|c|c|c|c|c|c|c|}
\hline \multirow{2}{*}{$\begin{array}{l}\text { Number of } \\
\text { experiments }\end{array}$} & \multicolumn{3}{|c|}{ Factors levels $^{c}$} & \multicolumn{4}{|c|}{ Responses } \\
\hline & $x_{1}$ & $x_{2}$ & $x_{3}$ & $\mathrm{Rt}$ & $\mathrm{T}$ & NTP & $\mathrm{Rs}$ \\
\hline 1 & -1 & 0 & 1 & 4.672 & 0.99 & 5494 & 5.98 \\
\hline 2 & 0 & 0 & 0 & 4.133 & 0.99 & 5253 & 5.53 \\
\hline 3 & 1 & 0 & 1 & 3.128 & 1.04 & 5967 & 6.30 \\
\hline 4 & 1 & 0 & -1 & 2.759 & 1.06 & 5961 & 5.80 \\
\hline 5 & -1 & -1 & 0 & 2.076 & 1.04 & 4497 & 4.52 \\
\hline 6 & 0 & -1 & 1 & 1.806 & 1.08 & 4307 & 4.15 \\
\hline 7 & 0 & 1 & 1 & 8.994 & 0.97 & 7253 & 7.30 \\
\hline 8 & 1 & -1 & 0 & 8.087 & 1.03 & 7543 & 7.24 \\
\hline 9 & 0 & -1 & -1 & 2.495 & 1.01 & 4429 & 4.26 \\
\hline 10 & -1 & 1 & 0 & 1.669 & 1.06 & 4869 & 4.46 \\
\hline 11 & -1 & 0 & -1 & 10.094 & 0.96 & 5200 & 7.11 \\
\hline 12 & 1 & 1 & 0 & 7.321 & 1.02 & 7651 & 7.67 \\
\hline 13 & 0 & 1 & -1 & 3.596 & 1.00 & 5420 & 5.85 \\
\hline 14 & 0 & 0 & 0 & 3.516 & 1.01 & 5366 & 5.83 \\
\hline 15 & 0 & 0 & 0 & 3.559 & 0.99 & 5370 & 5.78 \\
\hline
\end{tabular}

${ }^{c}$ Aberrations: $x_{1}$ - content of acetonitrile $(\%) ; x_{2}$ - flow rate; $x_{3}$ - column temperature;

$-1=$ low factor level, $1=$ high factor level

15 tests (including 3 replicates of the center point) were carried out in random order (Table 3 ).

Comparison of different proposed models from experimental trials for all responses favored quadratic model as a best fitted model. By applying ANOVA for the regression equations, all the resulting models were found to be significant, thus useful in predicting the effects of the factors on the selected responses. The magnitudes of the coefficients in the regression equations were used as a basis for judging statistical significance and illustrating the relative effects of linear, quadratic effects, as well as of the interactions between the parameters. The $\mathrm{p}$ value was used as an indicator of the significance of each coefficient, whereas $p$ value smaller than 0.05 being considered significant. The values of $\mathrm{R}^{2}$ shown in Table 4 indicate a good fitting, suggesting that the model adequately fits the real relationship between the parameters chosen in this study and is adequate for prediction within the range of experimental variables $\left(\mathrm{R}^{2}\right.$ $>0.9$ in all cases). To get more realistic model, through the backward elimination process, the insignificant terms with corresponding value higher than 0.05 were eliminated.

The adjusted values were well within the agreeable bounds of $\mathrm{R}^{2}$ which revealed that the experimental data is in good fit with the second order polynomial equations. Adequate Precision was in the range of 15-94, which showed an adequate signal and therefore the model is significant for the separation process. The coefficient of variation values for all the models were found in less than $10 \%$ (model can be advised sensibly reproducible if it is less than 10\%), indicating that the models were reproducible.
The relationship between the dependent and independent variables is illustrated using contour plot. The resulting graphs for all responses are presented in Figure 1.

The contour plots for all the evaluated responses were created keeping the temperature constant at $40{ }^{\circ} \mathrm{C}$. The coefficients of the second-order polynomial model were estimated by the least square regression analysis, and the function of responses related to the three selected factors was obtained.

From the obtained results, it can be concluded that the retention related parameters (Rt and Rs) are negatively influenced by the column temperature and positive influenced by the content of $\mathrm{CH}_{3} \mathrm{CN}$; however, the influence of temperature is less significant than the percentage of $\mathrm{CH}_{3} \mathrm{CN}$ and flow rate.

On the other hand, negative sign of coefficient before $x_{1} x_{3}$ and $x_{1} x_{2}$ evidence that the simultaneous increase of $\mathrm{CH}_{3} \mathrm{CN}$ content in the mobile phase and decrease of flow rate, as well as increase of $\mathrm{CH}_{3} \mathrm{CN}$ content in the mobile phase and decrease of column temperature, respectively, tend to prolong the retention. These factors proved to interact, however their interaction appeared to have insignificant effect on the responses.

All selected variables significantly influence the peak symmetry, but the values obtained for the peak tailing ranged from 0.96 to 1.08 , being therefore within the acceptable limits for all determinations.

The obtained results show that $\mathrm{CH}_{3} \mathrm{CN}$ content in the mobile phase strongly influenced the resolution.

Further, the optimal chromatographic conditions were chosen using desirability function, where the retention time of SIM was targeted to 3.6. The targeted resolution 
Table 4. The estimates of Box-Behnken regression analysis and statistical parameters of ANOVA

\begin{tabular}{lllll}
\hline \hline Statistical Parameters & $\mathrm{Rt}^{\mathrm{d}}$ & $\mathrm{T}$ & $\mathrm{NTP}$ & $\mathrm{Rs}$ \\
\hline Coefficient of regression $\left(\mathrm{R}^{2}\right)$ & 0.9987 & 0.8924 & 0.9950 & 0.9931 \\
Adjusted coefficient of regression & 0.9978 & 0.8494 & 0.9908 & 0.9912 \\
Predicted coefficient of regression & 0.9932 & 0.7439 & 0.9689 & 0.9856 \\
Lack of fit & $/$ & 0.1368 & 0.0549 & 0.089 \\
Predicted residual error sum of squares & 0.71 & 0.0044 & 496632 & 0.27 \\
Adequate Precision & 93.281 & 15.046 & 46.683 & 60.025 \\
Fischer's ratio (F-ratio) & 1045.03 & 20.73 & 233.83 & 528.07 \\
$p$ value & $<0.0001$ & $<0.0001$ & $<0.0001$ & $<0.0001$ \\
Coefficient of variation & 2.85 & 1.34 & 1.88 & 1.83 \\
& \multicolumn{2}{c}{ Regression equation } & \\
\hline Peak retention time (Rt) & $3.31 x_{1}-0.81 x_{2}-0.26 x_{3}-0.16 x_{1} x_{3}-0.49 x_{1} x_{2}+1.68 x_{1}{ }^{2}+3.64$ & \\
Tailing factor (T) & $-0.026 x_{1}+0.029 x_{2}+0.015 x_{3}+0.019 x_{3}{ }^{2}+1.01$ & \\
Number of theoretical plates (NTP) & $1455.74 x_{1}+246.70 x_{2}-18.26 x_{3}+119.93 x_{1} x_{3}+217.99 x_{2}{ }^{2}+449.02 x_{3}{ }^{2}+5423.23$ \\
Resolution (Rs) & $1.49 x_{1}+0.17 x_{2}-0.17 x_{3}+5.85$ & \\
\end{tabular}

${ }^{\mathrm{d}}$ Aberrations: $x_{1}$ - content of acetonitrile $(\%) ; x_{2}$ - flow rate; $x_{3}$ - column temperature;

between SIM and Simvastatin Impurity E was set in the range 5- 6, and a minimum theoretical plate of 5000 was imposed to the SIM peak. No specific limitations were imposed to the tailing factor, as its value falls within the acceptable range in all case in the experimental model (Figure 2).

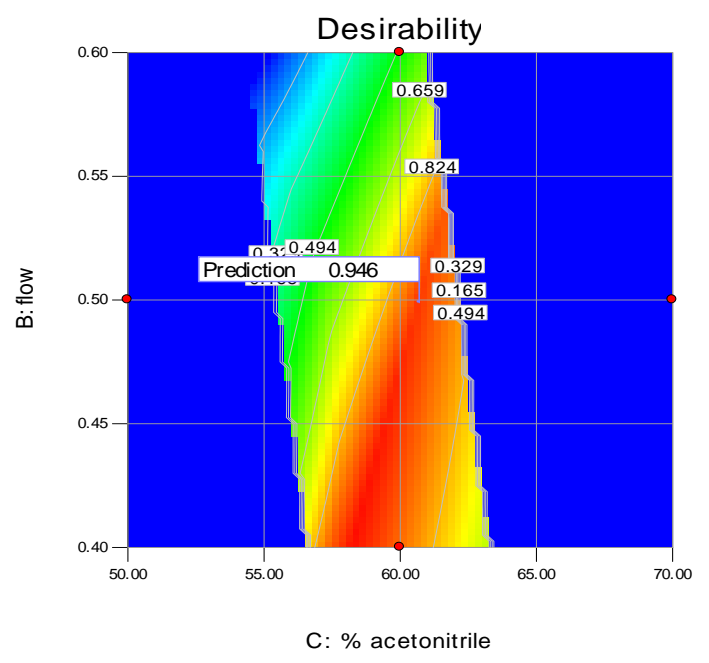

Fig. 2. Optimization of the selected responses by means of the desirability function, while column temperature maintained constant at $40{ }^{\circ} \mathrm{C}$.

From the desirability plot presented in Figure 2, it could be concluded that a set of coordinates producing high desirability value $(\mathrm{D}=0.946)$ are column temperature of $40{ }^{\circ} \mathrm{C}$, flow rate of $0.5 \mathrm{~mL} / \mathrm{min}$ and $60 \%$ of acetonitrile.
These chromatographic conditions were selected for further validation.

The predicted response values corresponding to the above optimum condition are given in Table 5. The comparison between the obtained and the predicted results was made, and noticeable difference was not observed (Table 5). The results of the experiments confirmed that the chosen model adequately reflects the expected optimization. Good predictability of the desirability plot provides valuable information about the method, saving considerable amounts of chemicals and experimental time.

In the development stage, evaluation of the robustness of the responses was done. In order to evaluate several factors in one experiment, a Plackett Burman design was employed. The obtained results are presented in Table 2. The statistical analysis (Table 6) indicates that the model successfully describes the analyzed responses with high statistical reliability.

Table 5. Comparison of experimental and predictive values of different responses under optimal conditions

\begin{tabular}{llll}
\hline \hline Parameters & Predicted & Obtained & Predicted Error \\
\hline $\mathrm{Rt}$ & 3.60 & 3.38 & 6.11 \\
$\mathrm{~T}$ & 1.00 & 0.97 & 3.00 \\
$\mathrm{NTP}$ & 5353 & 5682 & 6.15 \\
$\mathrm{Rs}$ & 5.81 & 5.57 & 4.13
\end{tabular}

Predicted Error $=($ Obtained values - Predicted $) /$ Predicted $* 100$

The impact of the investigated factors on the method's robustness could be determinate after graphical and statistical evaluation of the calculated factor effects. According to the previous published papers, it is 


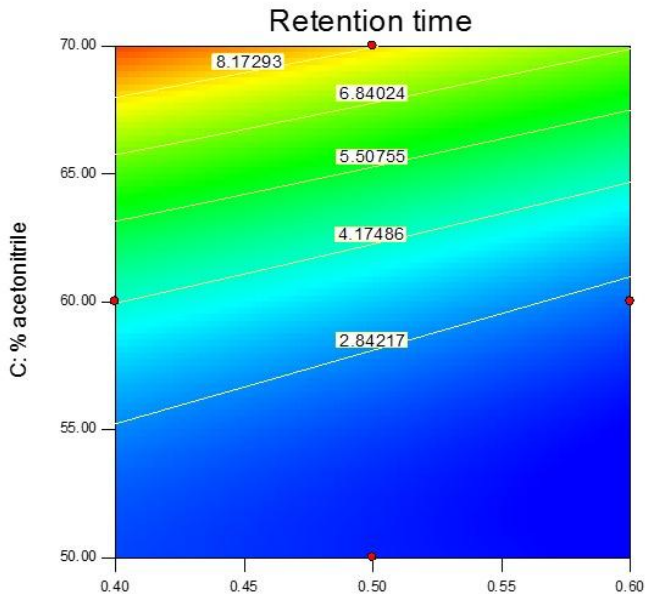

A: Temperature $40^{\circ} \mathrm{C}$

B: flow

a)

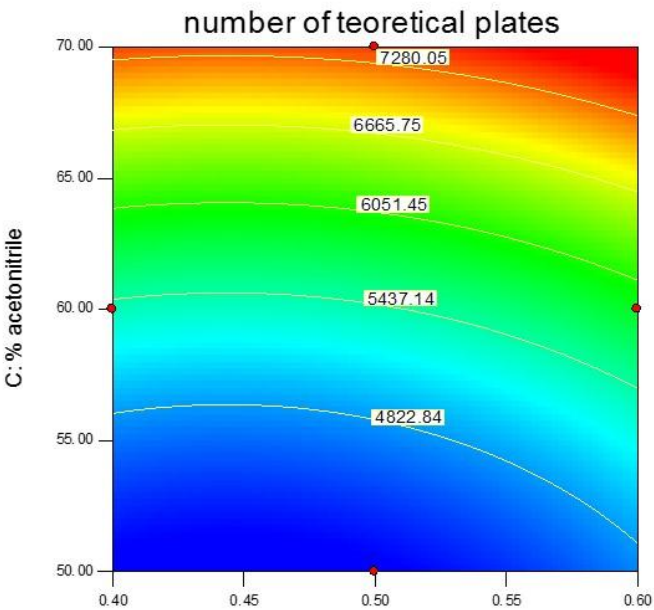

A: Temperature $40^{\circ} \mathrm{C}$

B: flow

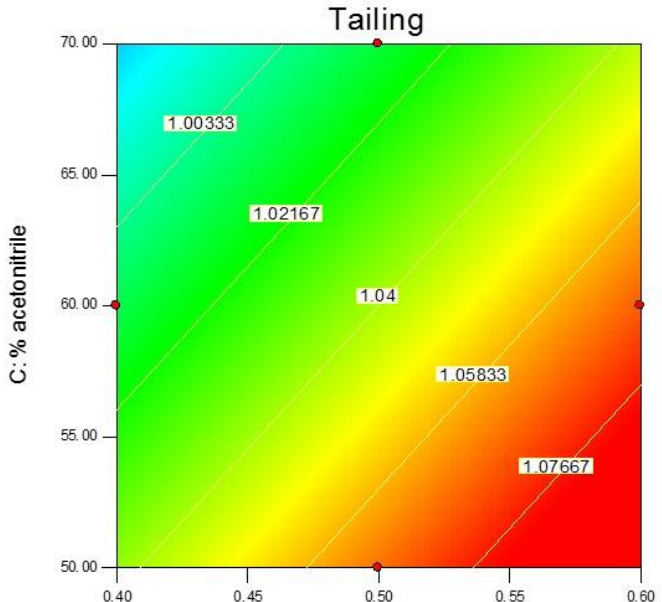

A: Temperature $40^{\circ} \mathrm{C}$

B: flow

b)

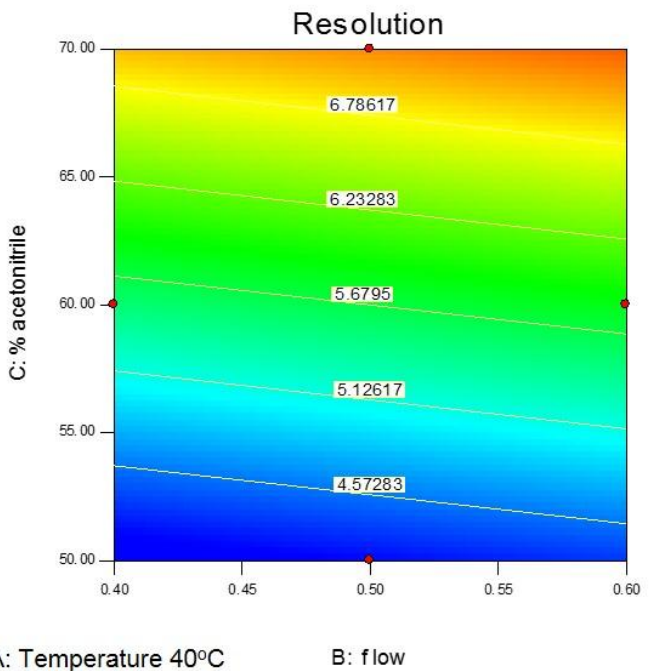

A: Temperature $40^{\circ} \mathrm{C} \quad$ B: flow

Fig. 1. Contour plots representing the retention time of SIM (a), tailing factor (b), number of theoretical plates (c) and resolution (d) as a function of \% organic modifier, column temperature and flow rate. Color change from gray to white represents increasing response values ( $\min \square \max$ ).

recommendable to use both approaches and compare the obtained results (Vanaja and Rani, 2007; Vander Heyden et al., 1999; Waters and Dovletoglou, 2003). In this study, first graphical evaluation by Pareto charts was made (Figure 3). Pareto charts estimate factor effects splitting the significant and non-significant ones by statistical tline. Factor effects that have higher value than the $t$ value are considered as significant. The obtained results are given in Table 6 .

After graphical estimation, statistical evaluation (which is considered as more precise and allows definition of limits for a certain factor) was employed. Two independent approaches were used (calculation of the experimental error using the effects of the dummy factors and evaluation by the algorithm of Dong). The dummy factor effects approach is based on comparing the factors effects to the effects of imaginary (dummy) variables, which are not expected to contribute the model.

Evaluation by the algorithm of Dong is based on initial estimation of the error based on the effect distribution and followed by calculation of the margin of error value (ME), which corresponds to critical effect. 
a)
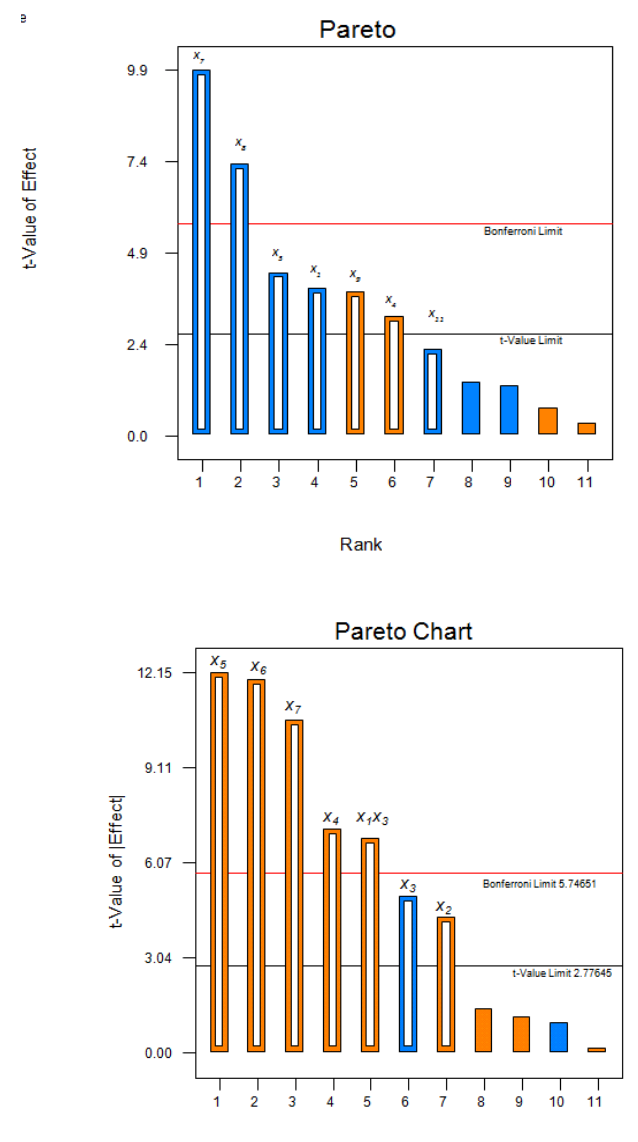

c)

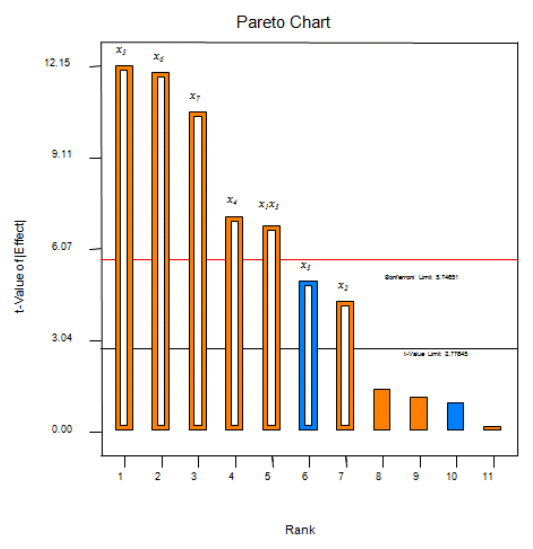

b)

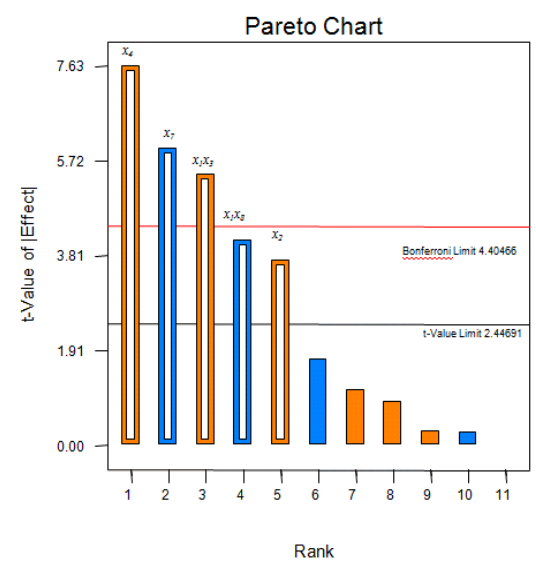

d)

Fig. 3. Pareto chart showing the significant effects based on the observation of Plackett Burman design for the investigated responses. a) Rt of SIM b) tailing factor for SIM c) number of theoretical plates d) Rs. $x_{1}$ : content of ammonium formate; $\mathrm{x}_{2}$ : wavelength; $x_{3}$ : column temperature; $x_{4}$ : column of the same composition but of different lot $x_{5}: \mathrm{pH}$ of the mobile phase $x_{6}$ : flow rate; $x_{7}$ : content of acetonitrile $(\%) ; x_{8}-x_{12}$ : dummy factors.

Table 6. Statistical parameters of ANOVA and obtained results from Plackett Burman model

\begin{tabular}{|c|c|c|c|c|}
\hline Statistical Parameters & $\overline{\mathrm{Rt}}$ & $\bar{T}$ & NTP & Rs \\
\hline Coefficient of regression $\left(\mathrm{R}^{2}\right)$ & 0.9872 & 0.9901 & 0.9792 & 0.9536 \\
\hline Adjusted coefficient of regression & 0.9647 & 0.9728 & 0.9427 & 0.9149 \\
\hline Predicted coefficient of regression & 0.8423 & 0.8367 & 0.7850 & 0.8253 \\
\hline Predicted residual error sum of squares & 5.03 & 0.0007 & 21250 & 1.36 \\
\hline Adequate Precision & 18.077 & 22.320 & 15.463 & 12.965 \\
\hline Fischer's ratio (F-ratio) & 43.95 & 53.70 & 26.86 & 24.65 \\
\hline $\mathrm{P}$ value & 0.0013 & 0.0008 & 0.003 & 0.0006 \\
\hline Coefficient of variation & 8.39 & 0.51 & 1.13 & 4.05 \\
\hline \multicolumn{5}{|c|}{ Effect evaluation } \\
\hline Significant effects from Pareto chart & $x_{1}, x_{4}, x_{5}, x_{6}, x_{7}$ & $x_{3}, \boldsymbol{x}_{\mathbf{4}}, x_{5}, x_{6}, \boldsymbol{x}_{7}, x_{1} x_{3}$ & $x_{1}, x_{2}, \boldsymbol{x}_{\mathbf{4}}, \boldsymbol{x}_{7}, x_{1} x_{2}, x_{1} x_{5}$ & $x_{4}, x_{7}, x_{1} x_{3}, x_{1} x_{8}$ \\
\hline Significant effects from dummies & $\boldsymbol{x}_{4}, x_{5}, x_{6}, \boldsymbol{x}_{7}$ & None & None & None \\
\hline Significant effects Dong algorithm & None & None & None & None \\
\hline $\mathrm{E}_{\text {critical }}$ & 0.68 & 0.05 & 338.40 & 0.05 \\
\hline Margin of error & 4.90 & $\mathrm{NA}^{\mathrm{e}}$ & NA & NA \\
\hline \multicolumn{5}{|c|}{ Non-significant interval obtained from $\mathrm{E}_{\text {critical }}$ from dummies at $\alpha=0.05$} \\
\hline$x_{7}$ & $59.94-60.06$ & $59.99-60.01$ & NA & $59.99-60.01$ \\
\hline
\end{tabular}


Table 7. Results from calculated effects at $\alpha=0.05$

\begin{tabular}{cccccccccccc}
\hline \hline Responses & \multicolumn{10}{c}{ Factors ${ }^{\mathrm{f}}$ व } \\
\hline & $x_{1}$ & $x_{2}$ & $x_{3}$ & $x_{4}$ & $x_{5}$ & $x_{6}$ & $x_{7}$ & $x_{8}$ & $x_{9}$ & $x_{10}$ & $x_{11}$ \\
\hline Rt & -0.32 & -0.35 & 0.54 & 1.74 & -0.82 & -2.16 & -2.03 & -0.06 & 0.40 & -0.02 & 0.28 \\
T & 0.013 & 0.003 & -0.01 & -0.01 & 0.03 & 0.03 & 0.04 & 0.003 & 0.003 & 0.023 & 0.03 \\
NTP & 261 & -41.76 & 107.7 & 198.33 & -101 & 216 & 111 & 148.7 & 7.0 & 109.0 & 159.0 \\
Rs & 0.01 & 0.003 & -0.01 & -0.01 & 0.03 & 0.03 & 0.04 & 0.003 & -0.003 & 0.02 & -0.03 \\
\hline
\end{tabular}

${ }^{\mathrm{f}}$ Aberrations: $x_{1}$ - content of ammonium formate $(\mathrm{mM}) ; x_{2}$ - wavelength; $x_{3}$ - column temperature; $x_{4}$ - column of the same composition but of different lot; $x_{5}$ - $\mathrm{pH}$ of the mobile phase; $x_{6}$ - flow rate; $x_{7}$. content of acetonitrile $(\%) ; x_{8}-x_{12}$ - dummy factors

The critical effects for the investigated system obtained with both approaches are presented in Table 6. If the factor effect value is lower than E critical or ME, the influence of that factor on the method's performance is not significant. The significance of the effects evaluated statistically is given in Table 6.

As expected, the column lot and the content of organic modifier were the most influential factors for the retention related parameters $\left(\mathrm{R}_{\mathrm{t}}\right.$ and $\left.\mathrm{Rs}\right)$.

After evaluation of the significance of effects, it is important to determinate non-significant intervals for significant effects (Vander Heyden et al., 1999). In this investigation, besides quantitative factors (concentration of buffer, mobile phase $\mathrm{pH}$ and temperature), the nonsignificant intervals for content of acetonitrile (Table 6) as a mixture factor were also calculated. The obtained results for all the responses analyzed were calculated for $\alpha$ $=0.05$ and are given in Table 7 .

As a confirmation of the chemometric approach, robustness of the method was checked by small deliberate changes of the method parameters such as wavelength $( \pm 2$ $\mathrm{nm})$, flow rate $( \pm 0.1 \mathrm{~mL})$, mobile phase ratio $( \pm 3 \%)$, and different column. The obtained results are presented in Figure 4 and as it could be seen the optimized method could be considered robust because changes of factors in defined ranges do not influence the investigated responses.

\section{Validation}

The developed and optimized method was validated as per ICH guidelines (Ich, 2005). The method was validated in terms of specificity, linearity, precision, accuracy, robustness, LOD and LOQ and stability.

The method was found to be specific, as no significant interfering peaks were observed at the retention time of main peak. Forced degradation studies of SIM were used to support the specificity and selectivity of the method, and it was found that degradants were adequately separated from SIM, thus the specificity and selectivity of the method was proven (Figure 5). Additionally, specificity was carried out by performing peak purity test for SIM during the forced degradation study.

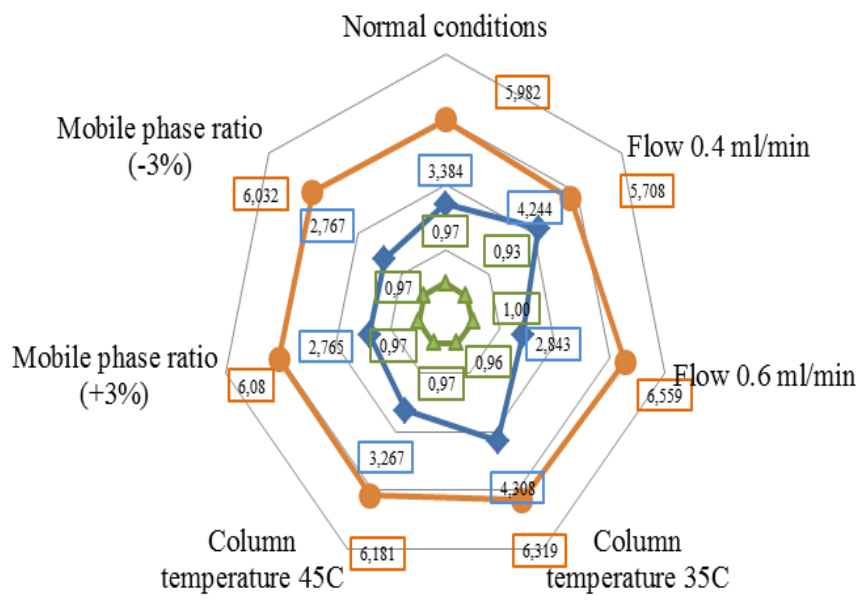

$\rightarrow$ Tailing $\rightarrow$ Retention time $\quad \longrightarrow$ Retention time $\quad+$ Number of theoretical plates

Fig. 4. Graphical representation of robustness testing one factor at time. 


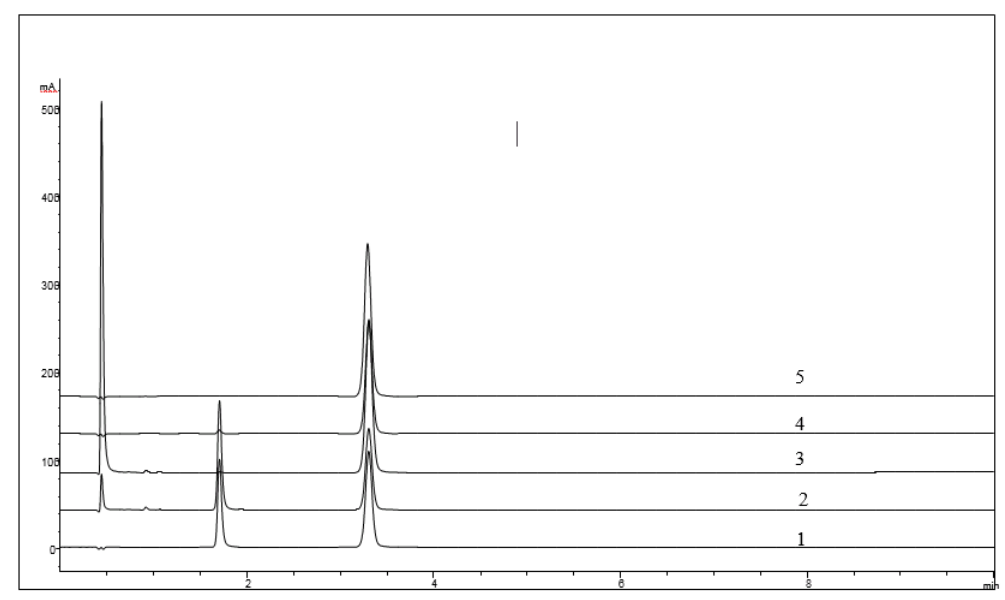

Fig. 5. Overlaid chromatographs from all degradation conditions like 1) Alkali degradation, 2) Acid degradation, 3) Oxidative degradation, 4) Thermal degradation and 5) Photo degradation.

Furthermore, the applicability of this method for determination of SIM in pharmaceutical preparations was evaluated by analyzing samples of commercially available tablets. The specificity is established by demonstrating that there is no interference between peaks of interest and peaks from diluent and placebo.

Under the proposed chromatographic conditions, satisfactory separation (Resolution 5.3) of SIM and Simvastatin Impurity E was achieved in total analysis time of 5 minutes (Figure 6).

The short chromatographic run time resulted in high method productivity and low cost of analysis per sample, compared with previous published studies, where analysis time was in range from 6-15 minutes (Table 9).

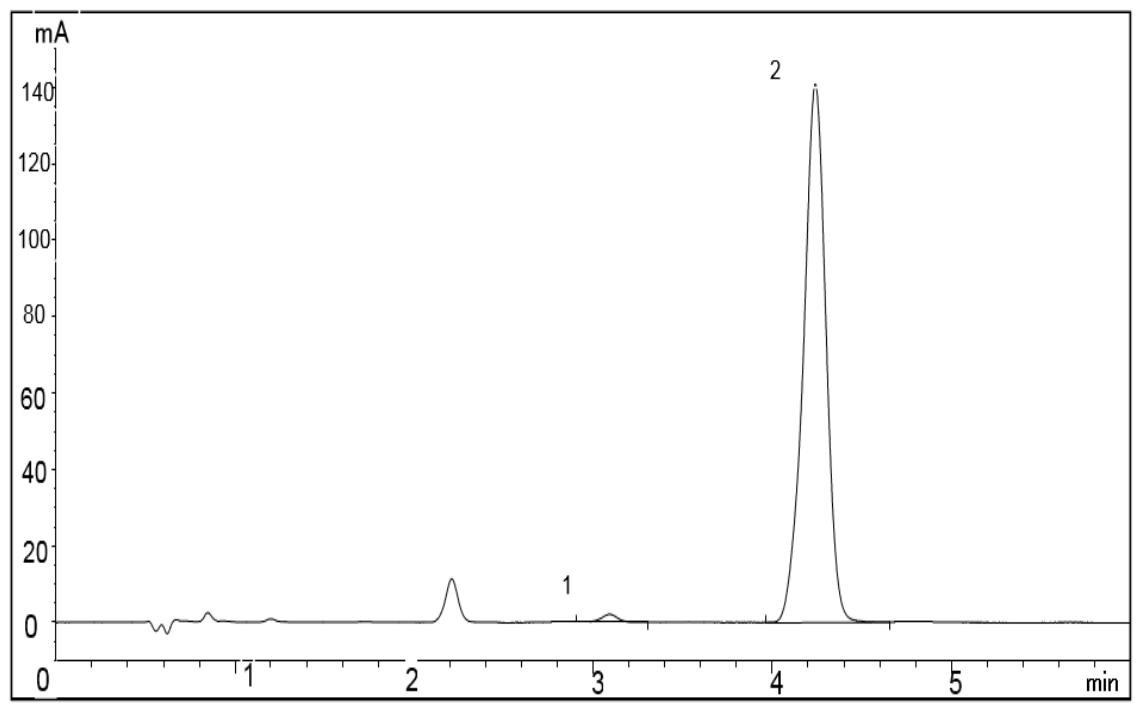

Fig. 6. Representative chromatogram of resolution solution where 1-Simvastatin Impurity E; 2-Simvastatin. 
Table 8. Important data for method validation

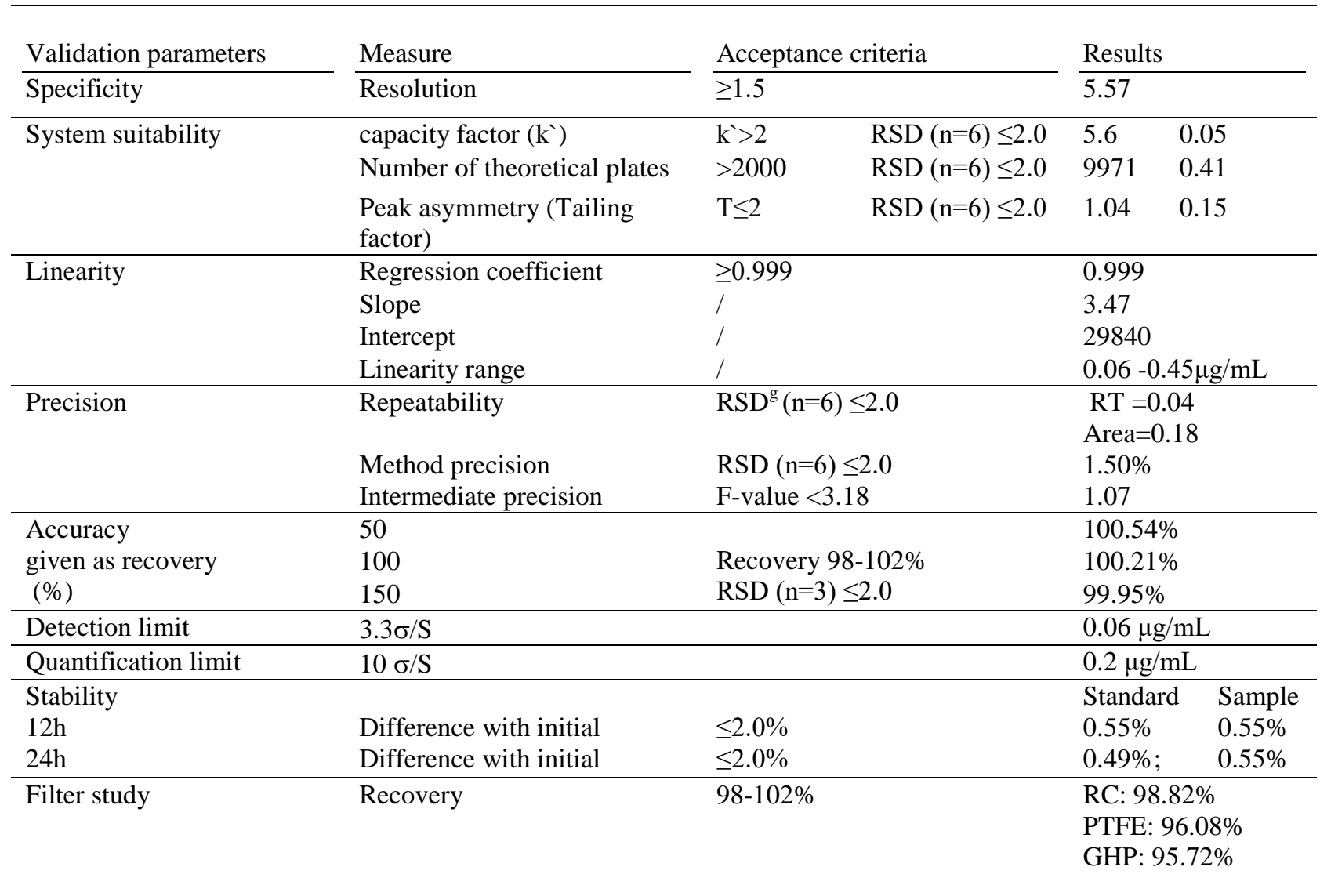

${ }^{\mathrm{g}}$ Aberration: RSD - Relative Standard Deviation

The system suitability parameters (including resolution, repeatability, capacity factor, tailing factor and number of theoretical plates) were calculated through six replicate injections of the standard and resolution solution. The RSD (\%) of all evaluated responses were within $2 \%$, indicating the suitability and good performance of the system (Table 8).

The method was found to be linear from 0.06 to 0.45 $\mu \mathrm{g} / \mathrm{mL}$ with correlation coefficient values 0.999 .

The mean percentage recovery was found to be 99.95-100.54\% respectively, showing the accuracy of the proposed method (Table 8).

The obtained results from repeatability and intermediate precision were within $\pm 2 \%$, indicating that the method is precise.

The LOD and LOQ were determined from the residual standard deviation of the regression line $(\sigma)$ and the slope (S). SIM could be detected at concentration of $0.06 \mu \mathrm{g} / \mathrm{mL}$, while the limit of quantification was confirmed by replicate injection of solution containing $0.18 \mu \mathrm{g} / \mathrm{mL}$ SIM. The obtained results for LOD and LOQ indicate a good sensitivity of the proposed method which appears to be more sensitive than the previously published methods (Table 9).
The stability study showed that standard solution and sample solutions are stable for 2 days at room temperature.

The results of filter compatibility studies showed that regenerate cellulose (RC) membrane filter was found to be suitable for this analysis (Table 8).

\section{Environmental evaluation}

The developed method was evaluated further with respect to environmental impact using HPLC Environmental Assessment Tool (HPLC-EAT), easy-touse software providing an indication about the environmental, health and safety impacts of the chromatographic method (Gaber et al., 2011). HPLCEAT calculate the impact of the solvents used in the analytical method and present an output score reflecting the greenness of the method.

HPLC-EAT scores were calculated for the suggested HPLC method and reported methods (Table 9). The proposed method proved to be more environmentally friendly, scoring very low on the scale, with good performance and validation parameters.

HPLC-EAT for the proposed HPLC method, gave a score 
Table 9. Comparison of LOD/LOQ, HPLC EAT - values of previous publish studies

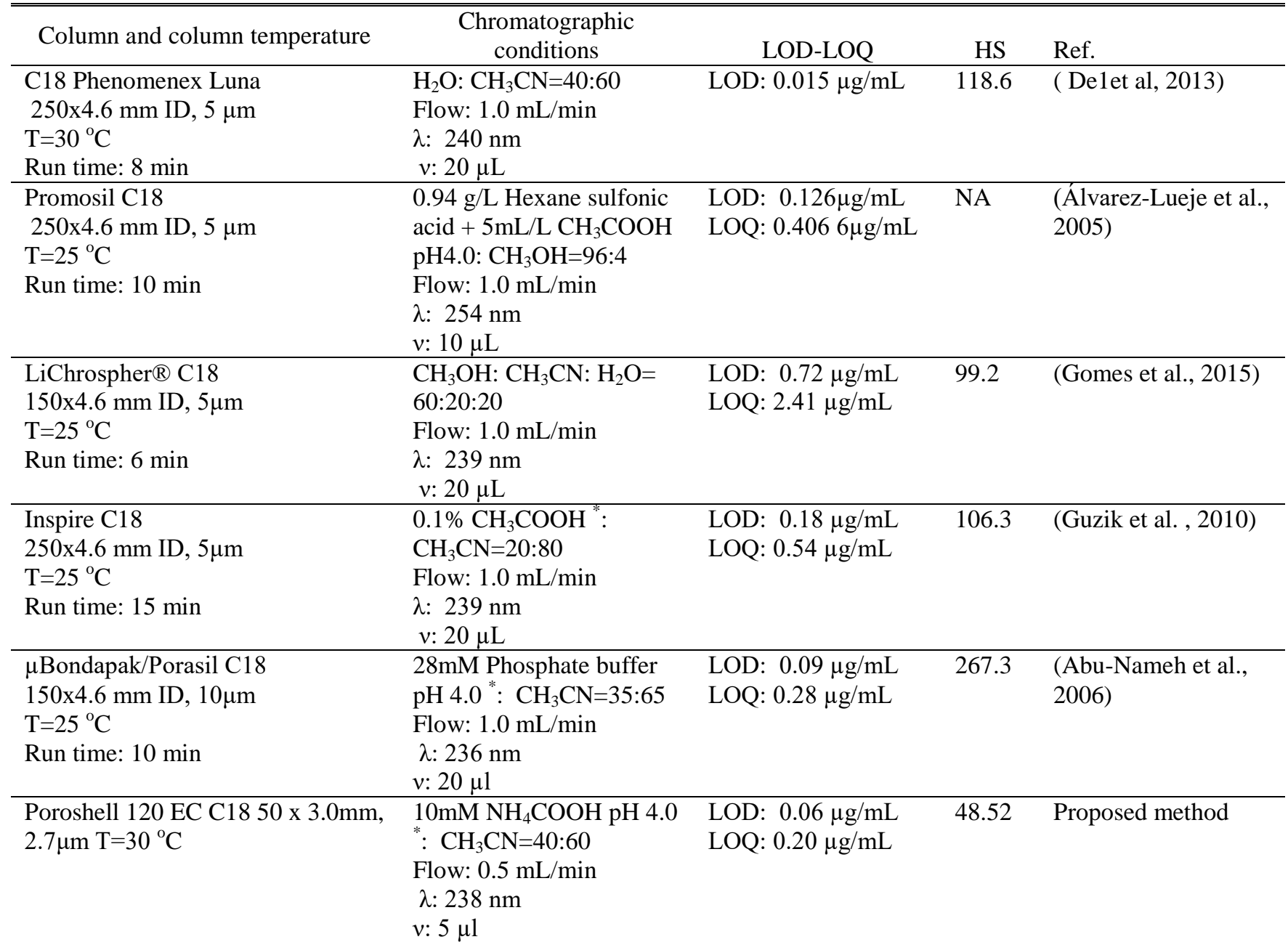

"generally recognized as safe -included in the calculation of HPLC-EAT as water solutions

HS- HPLC-EAT score

of 48.52 HPLC-EAT units and based on this, we could state that the proposed method is environmentally acceptable and lies within the HPLC-EAT score range of HPLC methods described for routine analysis.

\section{Conclusion}

The proposed methodology represents an efficient and easily accomplishable approach for resolving the problem of searching the optimum chromatographic conditions in minimum time. The optimized method represents an improvement over the existing reported methods especially in the terms of sensitivity, low cost per sample and "greenness" of the method. The validation study supported the selection of the chromatographic conditions by confirming that the method was specific, accurate, linear, precise, and robust. Therefore, this method can be used for routine pharmaceutical analysis of SIM as a drug substance and in pharmaceutical dosage forms. The investigation also showed that chromatographic techniques coupled with chemometric tools provide useful information of separation and elution time, making this combined technique a powerful analytical tool.

\section{References}

Abu-Nameh, E.S.M., Shawabkeh, R.A., Ali, A., 2006. Highperformance liquid chromatographic determination of simvastatin in medical drugs. Journal of Analytical Chemistry 61(1), 63-66. Available at: https://doi.org/10.1134/S1061934806010138. 
Álvarez-Lueje, A., Valenzuela, C., Squella, J.A., NúñezVergara, L.J., 2005. Stability study of simvastatin under hydrolytic conditions assessed by liquid chromatography. Journal of AOAC International 88(6), 1631-1636.

Bifulco, M., Endo, A., 2014. Statin: New life for an old drug. Pharmacological Research 88, 1-2. Available at: https://doi.org/10.1016/j.phrs.2014.06.005.

Cela, R., Ordoñez, E.Y., Quintana, J.B., Rodil, R., 2013. Chemometric-assisted method development in reversedphase liquid chromatography. Journal of Chromatography A 1287, 2-22. Available at: https://doi.org/10.1016/j.chroma.2012.07.081

De, A., Dey, S., Mandal, S.K., Pradhan, P.K., Patel, C., Shah, S. Lad, B., 2013. Development and validation of RP-HPLC method for the estimation of simvastatin in bulk and pharmaceutical dosage form. Indo American Journal of Pharmaceutical Research 3(3), 9.

Dejaegher, B., Vander Heyden, Y., 2011. Experimental designs and their recent advances in set-up, data interpretation, and analytical applications. Journal of Pharmaceutical and Biomedical Analysis 56(2), 141-158. Available at: https://doi.org/10.1016/j.jpba.2011.04.023.

Duarte, A.C., Capelo, S., 2006. Application of chemometrics in separation science. Journal of Liquid Chromatography and Related Technologies 29(7-8), 1143-1176. Available at: https://doi.org/10.1080/10826070600574929.

Ebrahimi-Najafabadi, H., Leardi, R., Jalali-Heravi, M., 2014a. Experimental design in analytical chemistry - Part I: Theory. Journal of AOAC International 97(1), 3-11. Available at: https://doi.org/10.5740/jaoacint.sgeebrahimi1.

Ebrahimi-Najafabadi, H., Leardi, R., Jalali-Heravi, M., 2014b. Experimental design in analytical chemistry - Part II: Applications. Journal of AOAC International 97(1), 12-18.

Ferreira, S.L.C., Bruns, R.E., da Silva, E.G.P., dos Santos, W.N.L., Quintella, C.M., David, J. M., de Andrade, J.B., Breitkreitz, M.C., Jardim, I.C.S.F., Neto, B.B., 2007. Statistical designs and response surface techniques for the optimization of chromatographic systems. Journal of Chromatography A 1158(1-2), 2-14. Available at: https://doi.org/10.1016/j.chroma.2007.03.051.

Gaber, Y., Törnvall, U., Kumar, M.A., Ali Amin, M., HattiKaul, R., 2011. HPLC-EAT (Environmental Assessment Tool): A tool for profiling safety, health and environmental impacts of liquid chromatography methods. Green Chemistry 13(8), 2021.

Ganorkar, S.B., Shirkhedkar, A.A., 2017. Design of experiments in liquid chromatography (HPLC) analysis of pharmaceuticals: analytics, applications, implications and future prospects. Reviews in Analytical Chemistry 36(3). Available at: https://doi.org/10.1515/revac-2016-0025.

Guzik, L., Mrozik, W., Kamysz, W., 2010. Determination of simvastatin in pharmaceutical dosage forms by optimized and validated method using HPLC/UV. Croatica Chemica Acta 83(4), 371-377.

Hibbert, D.B., 2012. Experimental design in chromatography: A tutorial review. Journal of Chromatography B: Analytical Technologies in the Biomedical and Life Sciences 910, 2 13. Available at: https://doi.org/10.1016/j.jchromb.2012.01.020.

ICH, 2005. ICH Topic Q2 (R1), 1994. Validation of Analytical Procedures: Text and Methodology. International Conference on Harmonization, 17. Available at: http://www.ich.org/fileadmin/Public_Web_Site/ICH_Produ cts/Guidelines/Quality/Q2_R1/Step4/Q2_R1__Guideline.p df.

Jat, R.K., Sharma, S., Rc, C., Rambir, S., Imran, A., 2012. Development and validation of reversed phase HPLC method for estimation of simvastatin in pharmaceutical dosage forms. Journal of Drug Delivery \& Therapeutics 2(3), 121-124. Available at: https://doi.org/10.22270/jddt.v2i3.133.

Mozaffarian, D., Nye, R., Levy, W.C., 2004. Statin therapy is associated with lower mortality among patients with severe heart failure. American Journal of Cardiology 93(9), 11241129. Available at: https://doi.org/10.1016/j.amjcard.2004.01.039.

Reddy, R., Mounika, A., Regula, J., Nakka, S., 2014. Development and validation of RP-HPLC method for simvastatin using lovastatin as internal standard. Journal of Drug Delivery \& Therapeutics 4(3), 171-174. Available at: https://doi.org/10.22270/jddt.v4i3.871.

Sirtori, R.C., 2014. The pharmacology of statins. Pharmacological Research 88, 3-11. Available at: https://doi.org/10.1016/j.phrs.2014.03.002.

Tripathi, K.D., 2008. Essentials of Medical Pharmacology 6th ed., New Delhi (India): Jaypee Brothers Medical Publications.

Vanaja, K., Rani, R.H.S., 2007. Design of experiments: Concept and applications of plackett burman design. Clinical Research and Regulatory Affairs 24(1), 1-23. Available at: https://doi.org/10.1080/10601330701220520.

Vander Heyden, Y., Jimidar, M., Hund, E., Niemeijer, N., Peeters, R., Smeyers-Verbeke, J., Massart, D.L., Hoogmartens, J., 1999. Determination of system suitability limits with a robustness test. Journal of Chromatography A 845(1-2), 145-154. Available at: https://doi.org/10.1016/S0021-9673(99)00328-3.

Waters, R.B., Dovletoglou, A., 2003. Evaluating HPLC assay robustness with experimental design. Journal of Liquid Chromatography and Related Technologies 26(18), 29752985. Available at: https://doi.org/10.1081/JLC120025411. 


\title{
Резиме
}

\section{Хемометриски пристап за развој, оптимизација и валидација на UPLC метод за определување на симвастатин}

\author{
Маја Хаџиева Гиговска ${ }^{* 1}$, Ана Петковска ${ }^{1}$, Благица Манчевска ${ }^{1}$, \\ Јелена Ацевска ${ }^{2}$, Наталија Наков ${ }^{2}$, Пацка Антовска ${ }^{1}$, Соња Угарковиќ ${ }^{1}$, \\ Анета Димитровска ${ }^{2}$ \\ ${ }^{1}$ Истражување и Развој, Алкалоид АД Скопје, Бул. Александар Македонски 12, \\ 1000 Скопје, Република Македонија \\ ${ }^{2}$ Фармацевтски факултет, Универзитет „Св. Кирил и Методиј“, Мајка Тереза 47, 1000 \\ Скопје, Република Македонија
}

Клучни зборови: хемометрија, дизајн на експерименти, UPLC/DAD, симвастатин

Во овој труд е прикажан хемометриски пристап во развојот, оптимизацијата и валидацијата на UPLC метод за определување на симвастатин во фармацевтски дозирани форми. Влијанието на клучните хроматографските фактори е проценето со примена на Box-Behnken дизајн. Оптимални хроматографски услови се постигнати на

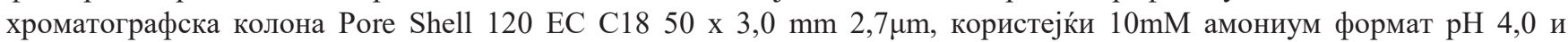
ацетонитрил како мобилна фаза. За утврдување на робусноста користен e Plackett-Burman дизајн и проценети се седум фактори (тип на колона, содржина на ацетонитрил, температура, $\mathrm{pH}$ на мобилна фаза, моларност на амониум формат, проток и бранова должина) во 12 експерименти. Предложениот метод е валидиран (според препораките на Меѓуународната конференција за хармонизација) во однос на специфичност, линеарност, точност, прецизност, осетливост и робусност. Резултатите од валидацијата покажаа дека предложениот метод е селективен, линеарен, осетлив (LOD $0,06 \mu \mathrm{g} / \mathrm{mL}$ и LOQ 0,18 $\mu \mathrm{g} / \mathrm{mL}$ ), точен и е погоден за определување на симвастатин во фармацевтски дозирани форми.

Предложениот метод има предности над претходно објавените трудови во однос на осетливоста и ниската цена на анализа. Дополнително има мало влијание врз околината поради што може да се карактеризира како еколошки прифатлив (,green“) метод. 